
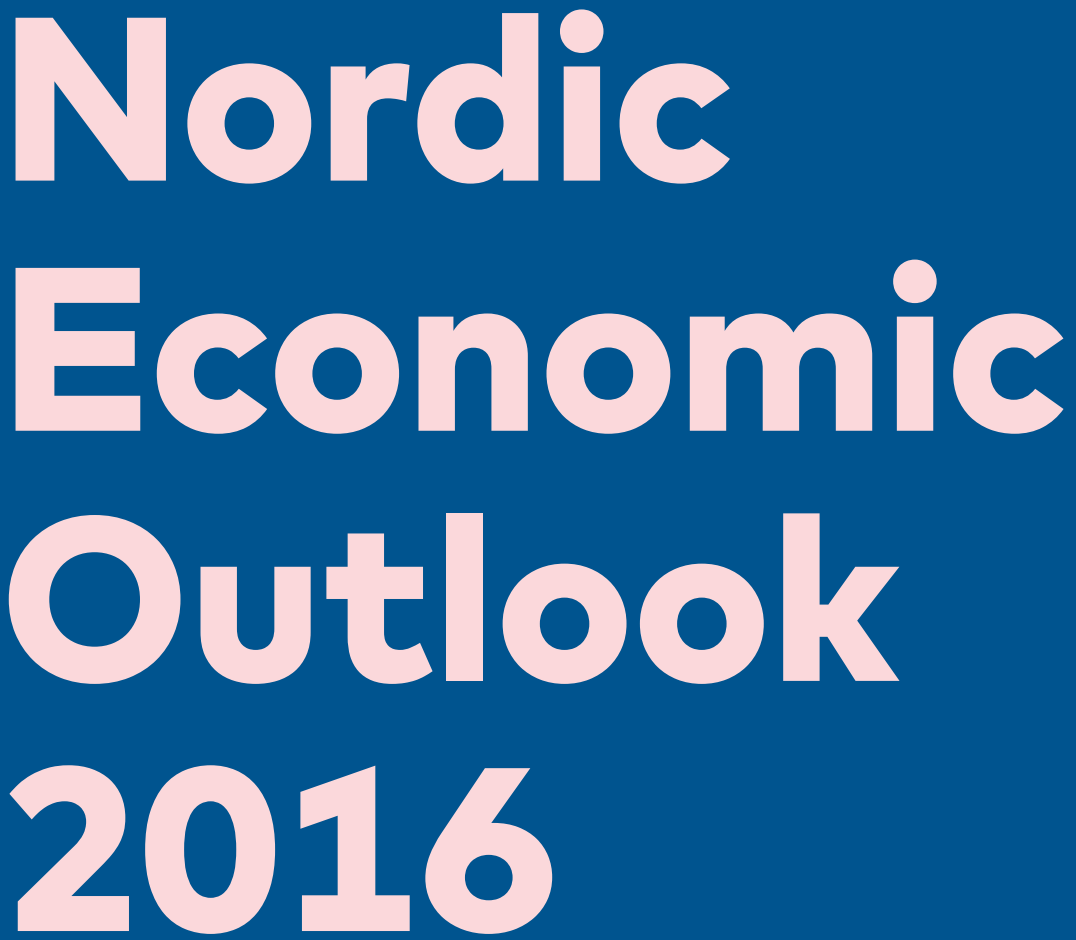

$\mathbb{1}$ Nordic Council of Ministers 


\section{Nordic Economic Outlook}

Nordiska konjunkturgruppen

TemaNord 2016:559 


\section{Nordic Economic Outlook}

Nordiska konjunkturgruppen

ISBN 978-92-893-4791-4 (PRINT)

ISBN 978-92-893-4792-1 (PDF)

ISBN 978-92-893-4793-8 (EPUB)

http://dx.doi.org/10.6027/TN2016-559

TemaNord 2016:559

ISSN 0.908-6692

Standard: PDF/UA-1

ISO 14289-1

(C) Nordic Council of Ministers 2016

Layout: Hanne Lebech

Printed in Denmark

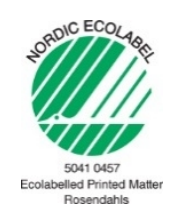

The content of this joint report is based on official Government documents from the Nordic countries. However, the opinions expressed in the text are those of the members of the Nordic Group of MacroAnalysts (Nordiska konjunkturgruppen), and do not necessarily reflect the official views of the Nordic countries or the Nordic Council of Ministers.

\section{Nordic co-operation}

Nordic co-operation is one of the world's most extensive forms of regional collaboration, involving Denmark, Finland, Iceland, Norway, Sweden, the Faroe Islands, Greenland, and Åland.

Nordic co-operation has firm traditions in politics, the economy, and culture. It plays an important role in European and international collaboration, and aims at creating a strong Nordic community in a strong Europe.

Nordic co-operation seeks to safeguard Nordic and regional interests and principles in the global community. Shared Nordic values help the region solidify its position as one of the world's most innovative and competitive. 


\section{Contents}

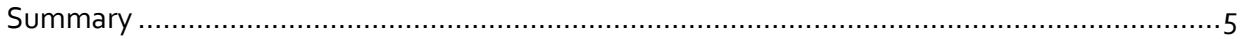

1. The Nordic and international economy ……….....................................................

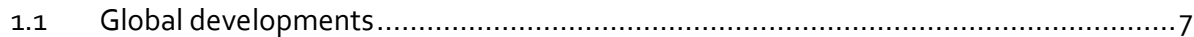

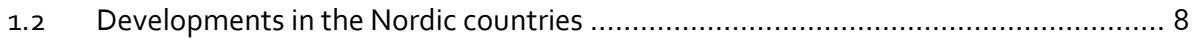

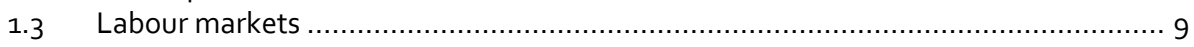

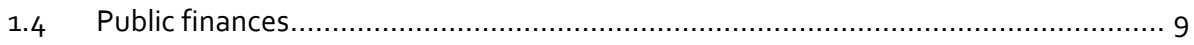

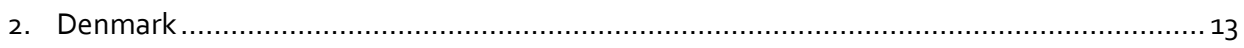

2.1 Short-term economic outlook for the Danish economy …….................................13

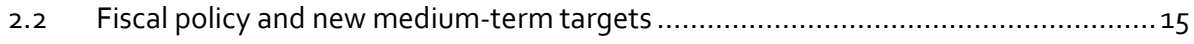

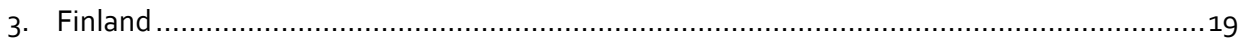

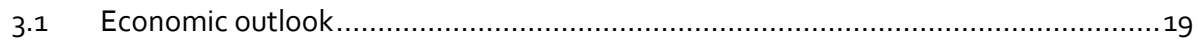

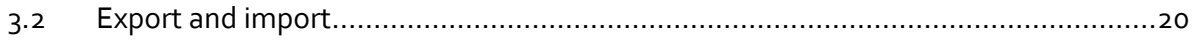

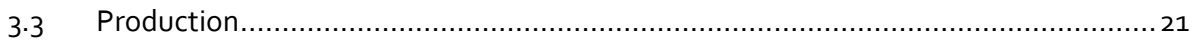

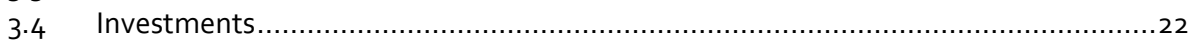

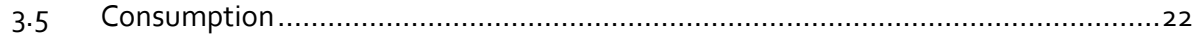

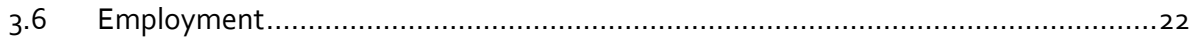

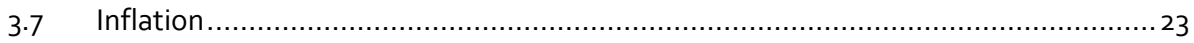

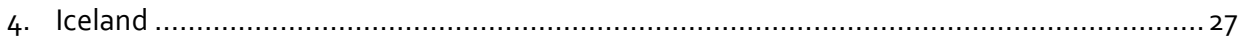

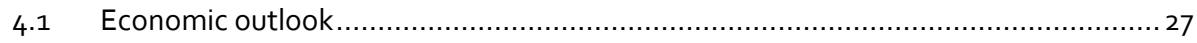

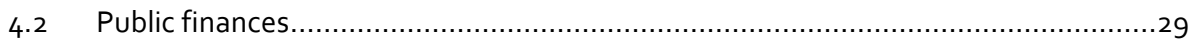

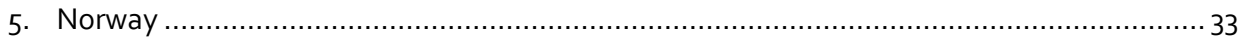

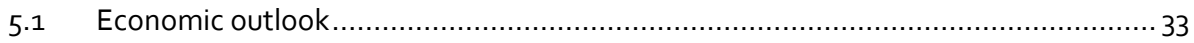

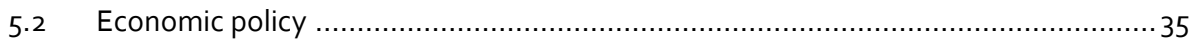

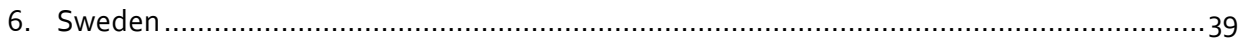

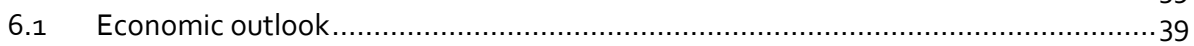

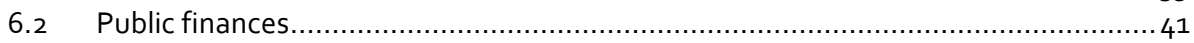

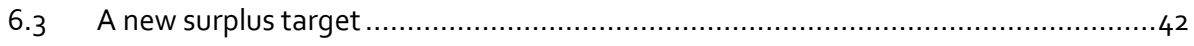

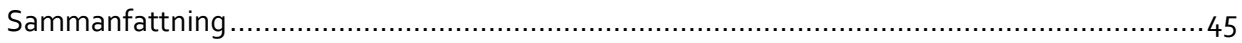





\section{Summary}

The present report of economic developments in the Nordic countries has been prepared by the Nordic Group of Macro-Analysts (Nordiska konjunkturgruppen). In Denmark, a moderate recovery is expected to continue due to stronger domestic demand. The positive outlook for private consumption should be seen in the context of strong developments in the labour market. Capacity utilisation is rising and investments are gradually picking up. Finland is currently in an economic upswing after the recession. Domestic demand is growing but exports continue to be a problem, partly due to lower demand from Russia. The Norwegian economy has been improving since the trough in the autumn of 2015 , which was caused by a substantial fall in oil prices. While consumers and business leaders have become more optimistic about the outlook of the economy, the low oil price continues to curb growth. Sweden and Iceland have enjoyed strong growth on the back of strong domestic demand, but growth rates are projected to slow. In Sweden, growth is underpinned by robust household consumption and investments. 



\section{The Nordic and international economy}

\subsection{Global developments}

The general economic recovery has continued in 2016, although global GDP growth continues to be moderate. The global economy is expected to grow by only around 3.1 percent in 2016, the slowest pace since the financial crisis. Inflation is low in most major economies and unemployment is decreasing very slowly, especially in the Euro area. Global GDP growth is expected to edge higher in the coming years, which will slightly increase trade growth.

Growth in the advanced economies is expected to be moderate. The British referendum in June 2016 resulted in the decision to leave the European Union. This was initially followed by large fluctuations on the international stock markets, falling government bond rates, and a sharp depreciation of the pound, but financial markets had broadly stabilised by the end of August 2016. Confidence indicators also suggest that the spillover effects to other economies have so far been limited. Consequently, growth in other countries is currently expected to be affected considerably less than in the UK. The negative effects on the British economy are expected to be somewhat dampened by expansionary monetary and fiscal policy, together with a weaker exchange rate.

Growth in the Euro area has accelerated in 2016 but is still spread unevenly across countries. While the German economy has strengthened, the Italian economy has remained weak. A stronger investment climate, underpinned by an expansionary monetary policy and low energy and commodity prices, is supporting the recovery. Growth in 2017 is expected to continue at the same pace as in 2016. Unemployment is expected to remain high and inflation low. Growth in the US economy slowed in early 2016, but this is partly attributable to a reduction in inventories, suggesting increased production in the coming quarters. Household consumption has continued to grow at a healthy pace, and a stable labour market development suggests a 
stronger performance in the second half of 2016 and during 2017. However, the result of the US presidential election has added to economic policy uncertainty, which in turn may affect real outcomes.

The economic conditions in emerging economies deteriorated sharply in 2015, due to falling prices of several key raw materials, but the situation has gradually improved over the course of 2016. However, challenges remain. The rebalancing of the Chinese economy is aimed at achieving more sustainable economic growth. Growth will increasingly be driven by consumption, having previously been dominated by exports and investments. Uncertainty about whether China will succeed with such a shift, without a significant slowdown in its economy, poses a risk to the global economy. Risks are associated with very high credit growth, adding to already high levels of debt in the private sector in China. In other commodity producing countries, such as Brazil and Russia, lower commodity prices have drastically reduced export revenues and triggered recessions. However, the prices of many commodities have been on the rise since the beginning of 2016, and this is expected to stimulate higher growth in several emerging economies in 2016 and 2017.

The risks forecast for the international economy, therefore, remain skewed to the downside. The sense of uncertainty is also expected to continue in the financial market. The situation in the Italian and to some extent the German banking sector is causing concern, and there is an apparent risk of contagion. It is impossible to make an overall assessment of the consequences of an unconventional monetary policy. In any event, the current environment of light monetary policy has created a stronger search-foryield mentality, and investment flows have been channelled into the housing and stock markets, partly because of the low demand for credit.

\subsection{Developments in the Nordic countries}

In Denmark, a moderate recovery is expected to continue due to stronger domestic demand. The positive outlook for private consumption should be seen in the context of strong developments in the labour market. Capacity utilisation is rising and investments are gradually picking up. Finland is currently in an economic upswing after the recession. Domestic demand is growing but exports continue to be a problem, partly due to lower demand from Russia. The Norwegian economy has been improving since the trough in the autumn of 2015, which was caused by a substantial fall in oil 
prices. While consumers and business leaders have become more optimistic about the outlook of the economy, the low oil price continues to curb growth.

Sweden and Iceland have enjoyed strong growth on the back of strong domestic demand, but growth rates are projected to slow. In Sweden, growth is underpinned by robust household consumption and investments. Despite some years of strong growth and increasing resource utilisation, inflation is still low. Inflation in Iceland is also low, mainly due to external factors such as low oil prices and low international inflation, along with an improving exchange rate.

\subsection{Labour markets}

The Nordic labour market is gradually improving, and unemployment is falling slowly in most Nordic countries. While the labour market in Norway is showing signs of stabilisation, workers in oil-related businesses are still feeling the effects of the slowdown in growth. Unemployment in the autumn of 2016 was increasing on a yearon-year basis. In Iceland, unemployment has fallen slowly since the financial crisis and is expected to remain low due to strong domestic demand. High demand for employment in Iceland has increased labour migration.

Unemployment rates are also decreasing in Denmark, Finland and Sweden. In Sweden, the strong economic growth has provided a boost for employment, and the unemployment rate is projected to fall to 6.3 percent in 2017, the lowest figure since 2010. Higher levels of employment have caused labour shortages in Denmark, while resource utilisation on the Swedish labour market is more balanced. In Finland, there are signs of optimism in the labour market, as employment and vacancies have started to pick up. Unemployment is expected to gradually fall over the coming years.

\subsection{Public finances}

Economic activity in Norway and Sweden is supported by an expansionary fiscal stance. In Norway, economic policy is highly expansionary. In 2016, petroleum and fund revenue spending will increase by 1 percent of trend GDP for mainland Norway, considerably above the average for the past 10 to 15 years. Fiscal policy will be less expansive in 2017. The general government finances in Finland will remain in deficit 
until the end of the decade, and the fiscal stance is broadly neutral. With the government reforms, public debt will stabilise in the short term and debt will fall towards 60 percent. In Sweden, the strong recovery of the economy and a prudent fiscal policy has helped to considerably strengthen the public finances in the past two years. The fiscal stance is projected to be somewhat expansionary in 2017, to accommodate the refugees that came to Sweden in 2015, and because of higher investments in the local government sector.

Iceland is now in its third consecutive year of a balanced budget. The primary surplus continues to be significant at 3.1 percent of GDP, which is currently larger than in most other countries. In Denmark, the budget proposal for 2017 implies a structural deficit of 0.4 percent of GDP, in line with the Budget Act. The budget proposal will have a slightly dampening effect on demand. This is in line with the need for a gradual adjustment towards the medium-term target, and to safeguard a sustainable recovery in view of highly accommodative monetary conditions. 
Table 1: Central macroeconomic variables

\begin{tabular}{|l|l|l|l|l|}
\hline 2013 & 2014 & 2015 & 2016 & 2017 \\
\hline
\end{tabular}

GDP growth, percent

\begin{tabular}{|c|c|c|c|c|c|}
\hline Sweden & 1.2 & 2.3 & 4.2 & $3 \cdot 5$ & 2.3 \\
\hline Iceland & & & 4.2 & $4 \cdot 3$ & $3 \cdot 5$ \\
\hline Finland & -0.8 & -0.7 & 0.2 & 1.1 & 0.9 \\
\hline Mainland Norway & 2.3 & 2.2 & 1.1 & 1.0 & 1.7 \\
\hline Denmark & -0.2 & 1.3 & 1.0 & 0.9 & 1.5 \\
\hline \multicolumn{6}{|l|}{ Inflation, percent } \\
\hline Sweden & 0.0 & -0.2 & 0.0 & 1.0 & 1.5 \\
\hline Iceland & & & 1.6 & 2.2 & 3.9 \\
\hline Finland & 1.5 & 1.0 & -0.2 & 0.4 & 1.1 \\
\hline Norway & 2.1 & 2.0 & 2.1 & 3.4 & 2.0 \\
\hline Denmark & 0.8 & 0.6 & 0.5 & 0.5 & 1.4 \\
\hline \multicolumn{6}{|c|}{ Unemployment (LFS), percent* } \\
\hline Sweden & 8.0 & 7.9 & $7 \cdot 4$ & 6.8 & 6.3 \\
\hline Iceland & $5 \cdot 4$ & 5.0 & 4.0 & $3 \cdot 4$ & $3 \cdot 4$ \\
\hline Finland & 8.2 & 8.7 & $9 \cdot 4$ & 9.0 & 8.8 \\
\hline Norway & 3.5 & $3 \cdot 5$ & 4.4 & 4.7 & 4.6 \\
\hline Denmark & 5.8 & 5.0 & 4.6 & 4.2 & 3.9 \\
\hline \multicolumn{6}{|c|}{ Current account balance, percent of GDP } \\
\hline Sweden & 6.0 & 5.4 & 5.8 & 5.7 & $5 \cdot 4$ \\
\hline Iceland & & & 3.8 & 2.6 & 2.9 \\
\hline Finland & -1.6 & -0.9 & 0.1 & 0.3 & 0.3 \\
\hline Norway & 10.2 & 11.0 & 8.7 & 4.5 & 4.9 \\
\hline Denmark & 7.1 & 7.7 & 7.0 & 6.8 & 6.6 \\
\hline
\end{tabular}

Note: * Registered unemployment in Denmark. 



\section{Denmark}

\subsection{Short-term economic outlook for the Danish economy}

The moderate upturn in the Danish economy is expected to continue. Employment has risen briskly, even though the pace of GDP growth has been modest. Productivity growth has been unusually subdued for the first phase of the upswing, partly because of the low rate of capital formation, and because employment growth is concentrated in the services sector. Moreover, declining oil and gas production is restraining GDP growth, but has not had much effect on employment.

Strong growth of 0.4 percent and 0.7 percent in the 1st and 2 nd quarters this year followed two consecutive quarters of negative growth in the 3 rd and 4 th quarters of last year.

GDP is projected to grow by 0.9 percent in 2016 and 1.5 percent in 2017. Although the pace of growth is slow, the moderate recovery is kept on track by strong underlying forces. Notably, an improving labour market, low inflation, and increasing housing prices, which are also boosted by low interest rates, serve as a firm foundation for increasing private consumption, which is projected to grow by 1.9 percent in 2016 and 1.6 percent in 2017.

As more people join the labour force, total income and confidence in future job opportunities are strengthened.

Real wages are projected to grow by about 1.25 percent on average per year. This is a relatively rapid increase in a historical perspective, and creates scope for increased private consumption and more investment in housing.

Furthermore, the low level of interest rates counteracts the dampening impact on housing prices of initiatives aimed at greater financial stability. These include the requirement for a minimum down payment of at least 5 percent when buying a home, which is likely to have contributed to banks tightening credit conditions towards households in the past year. Housing prices are expected to rise by 4 percent in each of the years 2016 and 2017. 
Following an extended period of low investment and stagnating capital stock, investment activity is expected to pick up. Capacity utilisation in manufacturing has been on the rise since 2012 and rose slightly above its historical average in the 3 rd quarter of 2016, for the first time since 2008. Meanwhile, machinery investments have increased.

Greater uncertainty, not least in the wake of Brexit, could make companies postpone some investments but, on balance, investment is projected to increase at a moderate pace over the forecast horizon, growing by 3.6 percent in 2016 and 4.7 percent in 2017.

While the basis for private consumption and investment seems to be gradually strengthening, the prospects for exports seem less certain. This is mainly due to greater uncertainty concerning the strength of global growth. New information and forecasts since the Brexit referendum suggest that the UK economy is likely to slow somewhat in the second half of 2016 and 2017, whereas the effects on other countries are likely to be more limited. Growth in Denmark's export markets is expected to continue, and export growth is projected to increase to 1.0 percent in 2016 and 3.3 percent in 2017.

The improvement in the labour market has been maintained, despite subdued growth in GDP. This trend, also observed in other advanced economies, is expected to last throughout the forecast period, and total employment is expected to increase by 62,000 (2.2 percent) between 2015 and 2017.

As more people find work, the total employment gap is expected to gradually shrink. The narrowing of the total employment gap coincides with a higher level of potential employment, as a series of reforms steadily increase the level of structural employment. The reforms seem to have enabled the marked increase in employment, without triggering widespread bottlenecks and capacity problems in general.

Nevertheless, the labour market is projected to tighten. Unemployment has fallen steadily to its lowest level in 40 years, with the exception of 2007-2008, when the economy was overheated. Unemployment is expected to fall further in 2016-2017, as employment increases towards the estimated structural level. The total unemployment gap represents only 0.5 percent of the labour force next year.

Rising capacity utilisation is also reflected in a growing number of businesses reporting greater production constraints due to labour shortages, especially in construction. The current situation is still some way from the extensive recruitment difficulties and bottlenecks that characterised the labour market in the years prior to the financial crisis, but the upward trend calls for vigilance. 
The economic outlook is subject to considerable uncertainty, not least as a consequence of the outcome of the Brexit referendum. The forecast is based on the assumption that there will still be confidence about the prospect of close ties between the EU and the UK after withdrawal.

Several downside risks are associated with developments in the global economy. Examples are a potential risk of weakening confidence in the banking sector in parts of the Euro Area, future risks relating to the Chinese economy, and potential geopolitical risks.

On the other hand, growth may turn out stronger than expected. Capacity pressures have intensified and, given low interest rates, businesses are in a good position to expand their investments at a faster pace. Similarly, private consumption may grow even faster, both domestically and abroad, which would generate positive spillover effects on both GDP and employment.

\subsection{Fiscal policy and new medium-term targets}

Although the rate of growth in the Danish economy is relatively modest, steady progress in the labour market is expected to continue and the output gap is expected to close by 2019. It is therefore important to maintain a prudent fiscal policy stance to reduce the risk of widespread labour shortages.

With the budget proposal for 2017, fiscal policy will have a slightly dampening effect on demand, and the structural public balance will also maintain a margin to the 0.5 deficit limit in the Budget Act.

For 2016 and 2017, the forecast projects budget deficits of 0.9 and 1.9 percent of GDP, which implies some distance to the 3 percent of GDP limit in the Stability and Growth Pact. The projected budget deficits should be seen in the light of expected changes in the pension yield tax revenues, which are often subject to large fluctuations. The expected revenues from the pension yield tax amount to 2.1 percent of GDP in 2016 and 0.6 percent of GDP in 2017.

For 2017, a structural deficit of 0.4 percent of GDP is projected, thereby maintaining a margin to the limit in the Budget Act. 
The one-year fiscal effect, which is a calculated measure of the effects of fiscal policy on economic activity relative to the previous year, is estimated at -0.1 percent of GDP in 2017, i.e. a modest tightening of fiscal policy. The prospects for monetary policy to remain accommodative underscore the need for prudent fiscal policies, to ensure that economic policy as a whole supports a stable recovery.

Alongside the budget proposal for 2017, the Danish Government has put forward a new medium-term economic plan, DK2025 - A Stronger Denmark (2025-plan). The 2025-plan sets a target of balancing the structural budget by 2025. The Government has also put forward new proposals to strengthen potential growth and labour supply. These will also expand the fiscal policy capacity for new initiatives and public service spending. The plan will also strengthen public finances in the long term by improving public finances towards 2040-2045, where the "hammock" in the projections for the structural deficit is deepest (cf. DK2025 - A Stronger Denmark).

The longer-term strengthening of public finances, together with initiatives to improve labour supply, increases the room for manoeuvre in the years towards 2020. Consequently, the target for the structural budget deficit in 2020 is eased from a balanced budget requirement to -0.25 percent of GDP. The relaxed deficit target in 2020 reduces the pressures on public finances arising from the downward adjustment to North Sea revenues and the inflow of refugees in the recent years.

Historically, medium-term economic plans have been essential in laying the ground for sound economic policies, which consider future economic challenges in good time. These plans have also helped secure a high level of confidence in public finances and in the Danish economy in general. 
Table 2: Key figures for the Danish economy

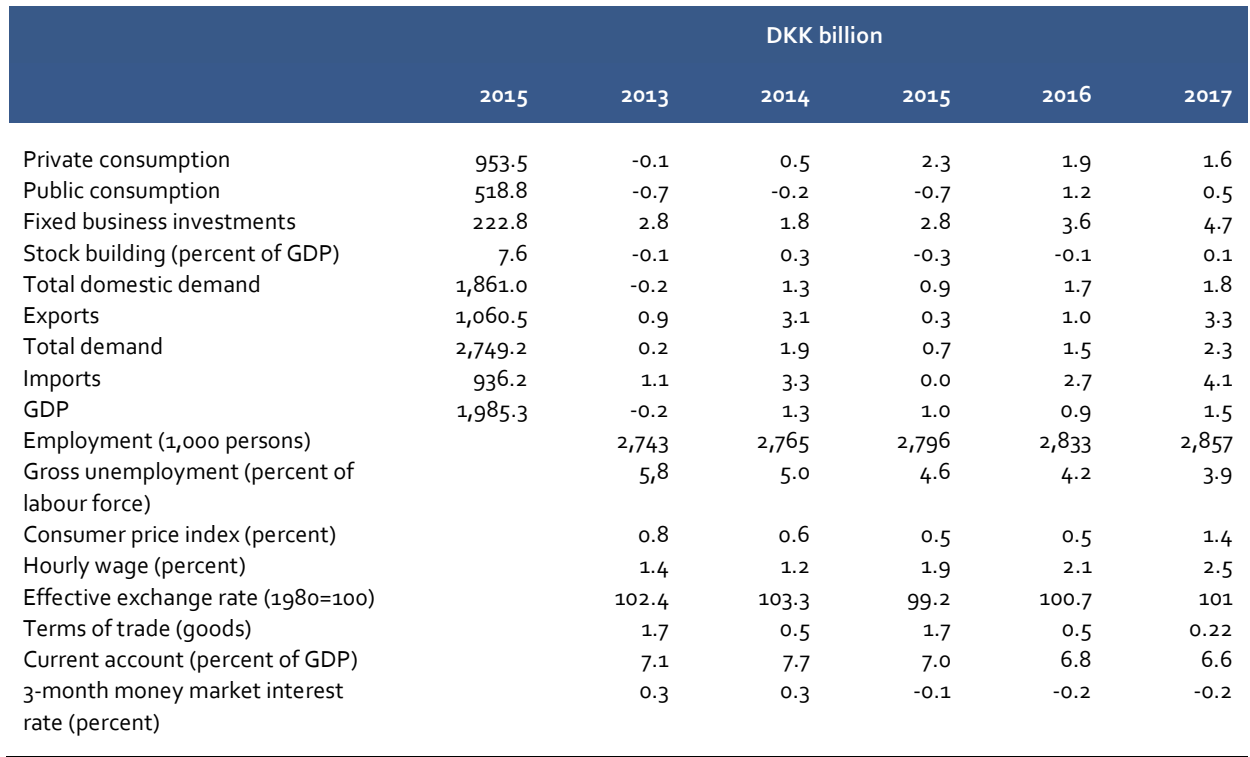

Source: Statistics Denmark and the Danish Ministry of Finance. The table is based on the August Economic Survey, updated where relevant with revised data with a cut-off date of October 18 . 



\section{Finland}

\subsection{Economic outlook}

The Finnish economy posted GDP growth of 0.2 percent in 2015, mainly driven by domestic demand. The year-on-year growth forecast for 2016 is 1.1 percent. Over the next two years, growth will hover around 1 percent, and cumulative growth for the whole outlook period will reach no more than approximately 3 percent.

Despite the slight rebound, the outlook for Finland's immediate future is one of continued economic weakness. The 2018 forecast is that GDP will still be some 2 percent lower than in 2008, and that industrial output will be around one-fifth lower than ten years ago. Export performance will remain weaker than global trade, and Finland will continue to lose market shares in world trade.

In the next few years, private consumption and investment will be the main drivers of economic activity. In the medium term, potential output growth, which reflects the level of output possible given the resources available, will be less than 1 percent.

Figure 1: Contribution to GDP growth in Finland (percentage points)

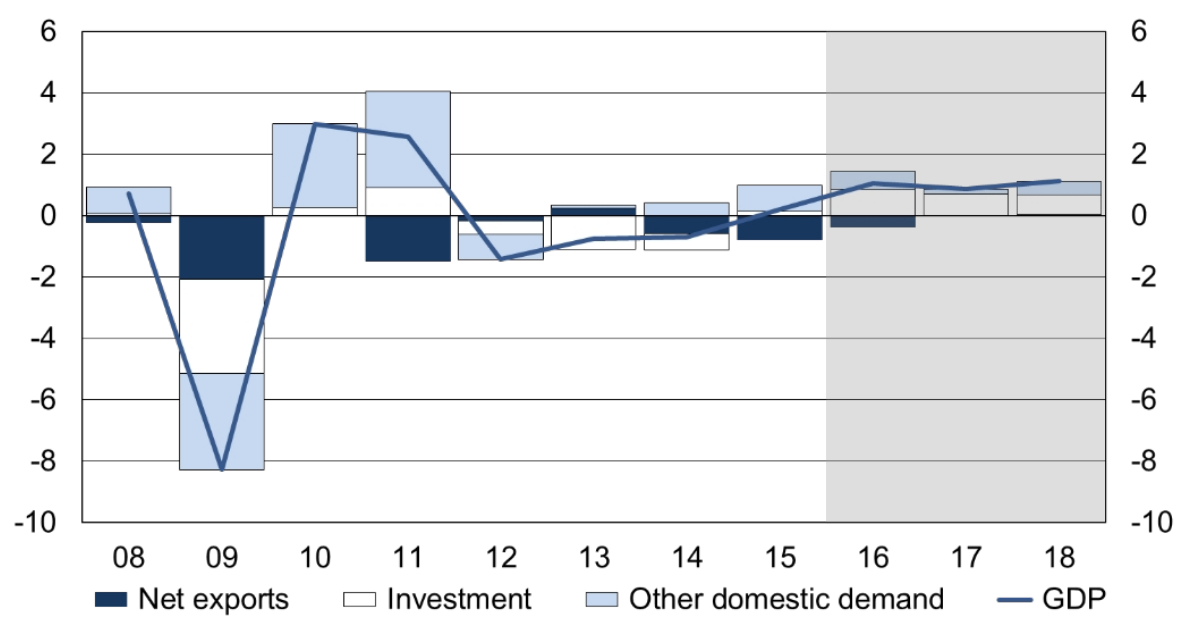


The outlook for growth in the global economy and trade has deteriorated recently. World trade growth will reach just 2 percent this year, one percentage point slower than global GDP growth. Global trade will pick up slightly but, even by the end of the forecast horizon, growth will reach no more than 4 percent. Many of Finland's major trade partners will see quite robust economic development. The Swedish economy will continue to grow at a good rate, the Euro Area will recover to moderate economic growth, and the UK's exit from the EU will primarily be a negative shock for the British economy. However, US economic growth will slow slightly.

Trends for earnings have a direct bearing on competitiveness and impact domestic cost trends. Nominal earnings will rise by just over 1 percent in 2016, the Competitiveness Pact will slow the index of wage and salary earnings to less than 1 percent, and employers' social security contributions will decrease by around 7 percent. Finnish competitiveness will improve in comparison with countries like Sweden and Germany.

Domestic risks are related to the development of the real economy and the labour market. Finnish economic growth has been dismal in the past few years, and it will continue to remain slower than in competitor countries over the next couple of years. The Finnish economy will be sensitive to negative shocks, and the growth rate will not be sufficient to bring a significant improvement to the labour market. The Government's employment target will not be reached and the growth of long-term and structural unemployment will scar the economy for a long time to come. The projected economic scenario will not significantly improve the health of public finances in Finland.

\subsection{Export and import}

Exports are predicted to grow slower than the rate of growth in the export markets over the forecast horizon. Slow export growth reflects several factors, the most significant of which relate to the structure of the export industry, Finland's poor cost competitiveness, and sluggish export demand. This year's growth in exports will be bolstered not only by the completion of a ship delivery, but also by exports of refined oil products recovering to their normal level.

Finland's competitiveness as measured by unit labour costs improved slightly last year over the Euro Area average. Over the outlook period, Finnish unit labour cost 
competitiveness will continue to improve, as the Competitiveness Pact drives down wage costs and boosts labour productivity growth.

Finland will continue to see its export market shares decline over the forecast horizon. Improving cost competitiveness will drive export growth towards the end of the outlook period. Economic growth in the Euro Area will be moderate, but the period of fastest growth has passed. However, the slight rebound in investment will improve the ability of Finnish export companies to retain their market shares.

In 2016, domestic demand will cause imports to increase. Accelerating export growth will increase the use of imported inputs in 2017 and 2018. The contribution of net exports to GDP growth will remain negative in 2016, but will turn positive as growth in exports gathers momentum during the outlook period.

As yet it is unclear how Finnish exports will be affected by the UK's vote to leave the EU. The bulk of Finnish exports to the UK consist of forest industry products. Finland also exports machinery and equipment to the UK, which will be more immediately affected by postponed investments in a climate of declining confidence. The forecast assumes that the Brexit vote will have only a marginal impact on Finnish exports, but there is a significant risk of weaker than anticipated export growth if the rest of Europe loses confidence.

\subsection{Production}

Industrial output continued to fall in 2016, and the forecast predicts a year-on-year decrease of 2.2 percent. Service output growth will be less than 1 percent, so output in general is very subdued in 2016 . In 2017, industrial output will finally return to growth of around 2 percent, mainly on the back of strong metal industry performance, but there is no significant recovery in sight for service production. Projected cumulative growth of total value added in 2016-2018 will reach no more than some 3.5 percent, and the level will remain some 4 percent lower than in 2008.

Production outlook risks are balanced. On the negative side, the global demand for Finnish manufacturing production may appear to be weaker than expected, either due to product portfolio mismatch or to wrong pricing of export goods. On the positive side, the Competitiveness Pact may produce positive results faster than expected in terms of cost competitiveness and greater world market shares. 


\subsection{Investments}

The most recent national accounts figures show that private investment was already up 2.2 percent in 2015 . The private investment forecast for the current year projects a growth rate of over 4 percent, which will then slowly decline over the coming years. Investment is primarily driven by construction. Robust growth will be recorded for investments in both residential and other building construction, and a significant increase will be seen in machinery and equipment investments.

However, R\&D will be adversely affected in the short term, both by cutbacks in public funding and by redundancies of private sector research staff. However, the forecast is that R\&D investment will return to growth in 2017 and gather further momentum in 2018 on the back of the improving global economy.

\subsection{Consumption}

Private consumption volume growth will slow somewhat to 0.7 percent, but will remain relatively strong compared with figures for disposable income. As a result of the Competitiveness Pact, nominal earnings will rise by no more than 0.8 percent. The improving employment situation will help boost private consumption.

In recent years, private consumption has increased more rapidly than disposable income, so the household savings rate has been decreasing almost without interruption since 2010. Low interest rates and ready access to loans have increased borrowing. The growth of the debt ratio has not even been halted by rising unemployment. The 6-12month loan repayment holidays marketed last year by banks to housing loan holders have further fuelled the growth of indebtedness.

\subsection{Employment}

Employment started to improve in the early part of the year. The number of persons employed will be 0.4 percent higher than last year, and the annual average unemployment rate is predicted to be 9 percent. The continuing rise in long-term and structural unemployment is a particular cause for concern. Earnings levels will rise 
slowly over the forecast horizon, and in 2016 the index of wage and salary earnings is expected to rise by 1.2 percent.

The annual GDP growth forecast for 2017 is 0.9 percent. In the labour market, employment will continue to edge up as the cycle improves. The employment rate will increase by 0.3 percent, and the projected unemployment rate is 8.8 percent. The Competitiveness Pact will cut labour costs in 2017, and wage levels are expected to rise only 0.8 percent. The Confederation of Finnish Industries, the largest employer organisation in Finland, has announced that it will not participate in centralised wage bargaining after 2017. Wage bargaining is moving towards industry, sector or local level, but the Finnish model of wage bargaining still applies.

Long-term and structural unemployment in Finland is high, with actual unemployment projected to remain around 9 percent in 2016. There are signs of optimism in the labour market, as employment and vacancies have started to pick up. Unemployment is expected to decrease gradually over the coming years, as employment continues to grow moderately. At the same time, the expansion of the labour force is limited by the ageing population.

\subsection{Inflation}

The inflation forecast for the current year is 0.4 percent, as measured by the national consumer price index. It is anticipated that the price of oil will begin to push up inflation, and that it will continue to have an upward effect through to the end of the forecast horizon in 2018. However, other inflationary pressures will remain lower than usual, as there are idle resources in the economy and the output gap is still clearly negative. The national consumer price index is expected to increase by 1.1 percent in 2017 and by 1.3 percent in 2018.

\subsubsection{Public finances}

General government finances will remain in deficit through to the end of the decade. Slow economic growth is not generating enough tax revenue to finance public expenditure, which is further exacerbated by the ageing population. For these reasons, public sector debt has been growing rapidly for several years, and the same trend is likely to continue in the years ahead. The budgetary position of general government 
would need to show a surplus of around 2 percent of GDP by the beginning of the next decade if it were to meet the expenditure pressures caused by the ageing population in the coming decades.

Within general government, the sector showing the biggest deficit is central government. In 2015, the central government deficit stood at over EUR 6 billion. The deficit is expected to shrink to less than half the current figure by the end of the decade. The deficit in local government is also projected to decrease over the forecast horizon. However, the growing demand for social and health care services caused by population ageing will cause mounting expenditure pressure in the local government sector over the longer term. Nonetheless, the combined deficit of central and local government will remain high throughout the outlook period.

The surplus of earnings-related pension funds has decreased in recent years, as pension expenditure has grown rapidly and low interest rates have dented investment income. It is projected that the financial position of earnings-related pension funds will continue to weaken over the forecast horizon. Other social security funds have already been in deficit for the past two years because of rising unemployment. Over the forecast horizon, the position of other social security funds will be boosted by the unemployment insurance contribution hike and the slowly improving employment situation.

The Finnish public deficit exceeded the EU Treaty's 3 percent GDP reference value in 2014, but in 2015 the deficit fell below the limit. The deficit will remain under the limit throughout the forecast horizon. The public debt-to-GDP ratio has climbed to over 60 percent. There is a risk of significant deviation from the structural balance MTO next year.

The Government of Prime Minister Juha Sipilä has set itself the target of halting the growth in the public debt-to-GDP ratio by the end of the government term, and putting an end to living on debt by 2021. To complement and clarify this debt objective, the Government has specified targets for the general government budgetary position that concern, on the one hand, the financial position of central government, local government and social security funds during the government term, and on the other, the medium-term structural balance of general government. If these targets are met, budget balance in general government should virtually be restored by the end of the mandate period.

Fiscal policy objectives are interim steps on the road to public finance sustainability. These objectives will be attained through, for example, immediate savings, promoting 
efficiency in public administration and service production, and steps to improve the conditions for economic growth.

As well as specifying fiscal policy objectives, the Government has set the target of increasing the employment rate to 72 percent and the number of employed persons by 110,000 during its term in office. The measures aimed at increasing employment and reducing unemployment will promote growth and strengthen public finances.

The immediate savings measures outlined in the Government Programme are entered in the central government spending limits and included in the State Budget. These measures apply to some EUR 4 billion of total EUR 10 billion targeted savings. The remaining EUR 6 billion depends upon the outcomes of restructuring measures designed to strengthen public finances and measures to increase employment.

Preparations for social and health care reform are proceeding according to plan. Together with other measures designed to improve efficiency in public administration, the reforms have the potential to strengthen public finances by EUR 4 billion, but only in the longer term.

Moderate wage settlements, the Competitiveness Pacts and the associated cuts in taxation will boost employment and economic growth. The Government is also committed to supporting growth through investments and guarantees. Public investment is at a high level and public sector guarantees have increased very rapidly in recent years. However, it seems that, without further measures, the goals set for employment, the number of employed persons, and the improvements targeted for the general government budgetary position will not be reached.

High employment and productivity are crucial to economic growth and the stability of public finances. In its 2017 budget negotiations, the Government reached agreement on a new set of measures to support employment and growth. Even with these reforms in place, obstacles remain to employment and productivity growth that must be removed. This is the only way to effectively improve the outlook, and to create capacity for movement in public finances in the short term as well. 
Table 3: Key figures for the Finnish economy

\begin{tabular}{|c|c|c|c|c|c|c|c|}
\hline & 2015 & 2013 & 2014 & 2015 & 2016 & 2017 & 2018 \\
\hline & EUR billion & \multicolumn{6}{|c|}{ Percent change } \\
\hline GDP at market prices & 209 & -0.8 & -0.7 & 0.2 & 1.1 & 0.9 & 1.1 \\
\hline Imports & 78 & 0.5 & -0.2 & 1.9 & 2.0 & 2.9 & 3.6 \\
\hline Total supply & 287 & -0.4 & -0.6 & 0.7 & 1.3 & 1.4 & 1.8 \\
\hline Exports & 77 & 1.1 & -1.7 & -0.2 & 1.0 & 3.0 & 3.8 \\
\hline Consumption & 167 & 0.0 & 0.3 & 1.1 & 0.8 & 0.1 & 0.4 \\
\hline - private & 116 & -0.5 & 0.6 & 1.5 & 1.2 & 0.7 & 0.6 \\
\hline - public & 51 & 1.1 & -0.5 & 0.4 & -0.1 & -1.3 & 0.0 \\
\hline Investment & 43 & -4.9 & -2.5 & 0.7 & $4 \cdot 3$ & $3 \cdot 3$ & 2.9 \\
\hline - private & 35 & -6.6 & -3.4 & 2.2 & $4 \cdot 3$ & 3.9 & 3.8 \\
\hline - public & 8 & 2.6 & 0.9 & -5.1 & $4 \cdot 3$ & 0.6 & -0.8 \\
\hline \multicolumn{8}{|l|}{ EUR billion } \\
\hline GDP & & 203 & 205 & 209 & 213 & 218 & 223 \\
\hline Current account & & -3.3 & -1.9 & 0.3 & 0.6 & 0.7 & 0.7 \\
\hline \multicolumn{8}{|l|}{ Percent change } \\
\hline Services, change in volume & & -1.4 & -0.5 & 0.8 & 0.8 & 0.8 & 0.9 \\
\hline Industry, change in volume & & 0.0 & -0.5 & -2.5 & -2.2 & 1.9 & 2.6 \\
\hline Labour productivity, change & & 0.5 & -0.1 & 0.2 & 0.0 & -0.3 & 1.0 \\
\hline Employed labour force, change & & -1.0 & -0.4 & -0.4 & 0.4 & 0.3 & 0.5 \\
\hline Employment rate & & 68.5 & 68.3 & 68.1 & 68.5 & 68.8 & 69.3 \\
\hline Unemployment rate & & 8.2 & 8.7 & 9.4 & 9.0 & 8.8 & 8.5 \\
\hline $\begin{array}{l}\text { Consumer price index, change, } \\
\text { percent }\end{array}$ & & 1.5 & 1.0 & -0.2 & 0.4 & 1.1 & 1.3 \\
\hline Index of wage and salary earnings & & 2.1 & 1.4 & 1.3 & 1.2 & 0.8 & 1.2 \\
\hline $\begin{array}{l}\text { Short-term interest rates } \\
\text { (3-month Euribor) }\end{array}$ & & 0.2 & 0.2 & 0.0 & -0.3 & -0.3 & -0.1 \\
\hline $\begin{array}{l}\text { Long-term interest rates } \\
\text { (10-year govt. bonds) }\end{array}$ & & 1.9 & 1.4 & 0.7 & 0.3 & 0.4 & 1.0 \\
\hline \multicolumn{8}{|l|}{ Percent of GDP } \\
\hline Tax ratio & & 43.7 & 43.9 & 44.1 & $44 \cdot 3$ & $43 \cdot 3$ & 42.9 \\
\hline General government net lending & & -2.6 & -3.2 & -2.8 & -2.4 & -2.6 & -2.0 \\
\hline Central government net lending & & -3.7 & -3.7 & -3.0 & -2.8 & -2.8 & -2.3 \\
\hline General government gross debt & & $55 \cdot 4$ & $59 \cdot 3$ & 62.6 & $64 \cdot 3$ & 65.8 & 66.4 \\
\hline Central government debt & & 44.1 & 46.3 & $47 \cdot 7$ & $49 \cdot 7$ & 51.2 & 52.1 \\
\hline General government expenditure & & $57 \cdot 5$ & 58.1 & 57.7 & $57 \cdot 4$ & 56.6 & 55.9 \\
\hline Current account & & -1.6 & -0.9 & 0.1 & 0.3 & 0.3 & 0.3 \\
\hline
\end{tabular}

Source: Statistics Finland and the Finnish Ministry of Finance. 


\section{Iceland}

\subsection{Economic outlook}

In November 2016, Statistics Iceland forecast GDP growth in Iceland to be 4.8 percent in 2016, 4.4 percent in 2017 and around 2.7 percent per year until 2021. Economic growth has averaged 2.7 percent for the past five years, with an increase in jobs and investment. The current short-term goal of economic policy is to maintain stability, as recent collective bargaining agreements conflict with the goal of price stability. However, the agreements made last year have not yet triggered an increase in inflation, which is kept low because of external factors, such as low oil prices and low international inflation, along with an appreciating exchange rate.

The main risk factors to the forecast are the lifting of capital controls and overheating in the economy. International economic developments and geopolitical factors can also influence the forecast, especially low inflation and low policy rates in main trading countries, which affect domestic inflation and capital flows to and from the country. Economic stagnation in Iceland's main trading partners is also a concern and could have negative effects on the terms of trade.

The robust growth projected this year and beyond is driven by increased domestic demand, particularly private consumption, which grew by 4.3 percent in 2015 and is expected to grow by 7.1 percent in 2016. Increased purchasing power is the main factor driving the growth in private consumption. Strong investment growth also drove the economic growth of 2015, as gross fixed capital formation was 18.3 percent and is expected to be around 21.7 percent by the end of this year.

Inflation is projected to rise over target throughout the forecast period, reducing the growth of purchasing power from 2017 onwards. The household debt relief for index-linked mortgages came into effect at the start of 2015, leading to a wealth effect and lower debt service, which further boosts private spending. A third-pillar pension scheme to pay down debt has counteracted this somewhat and encourages households to save. Household debt will continue decreasing until 2019 as a result of this scheme. 
The forecast projects an annual public consumption growth of 1.0 to 1.8 percent over the period. This is somewhat below the long-term average of 2.2 percent. Public consumption was 24 percent of GDP last year, one of the highest rates among OECD countries.

Investment is reaching its long-term average. The recent increase in investment is largely driven by large energy-intensive projects and major developments in tourism, especially hotels. Investment growth will slow in 2017 as large-scale industrial projects are completed. Public investment will be kept low over the next few years to prevent overheating in the economy.

The level of investment fell sharply after the crisis but the authorities have tried to stimulate investment through agreements that include tax incentives for investors, mainly for larger projects like silicon plants. An "Innovation Bill" was passed in May 2016, offering deferred taxation of capital gains from stock options or bondsconverted-to-shares, tax relief for foreign specialist employees, tax relief to investors who purchase new shares in small enterprises, and increased R\&D tax relief for innovation projects. The aim of the bill was to support the financing of small and innovative firms.

Following the financial crisis, construction fell beyond the levels necessary to meet demand, but has now picked up as household economies have stabilised. Housing prices have risen and 1,500-1,800 units need to be completed every year to keep up with increased demand. However, in the five-year period 2009-2013, only 1,900 units were started. Building costs relative to housing prices have remained high, and this is the main reason for weak investment in the past few years. However, recent increases in housing prices have reduced the ratio of building cost relative to housing prices, and the forecast projects a substantial increase in housing investment to continue until 2021.

Surveyed unemployment (Labour Market Survey) is expected to be 3.1 percent in 2016 and 3.0 percent in 2017. Registered unemployment is somewhat lower, and was 2.9 percent in 2015. It is expected to drop to 2.5 percent in 2016 and gradually decline to 2.0 percent in 2018. The improvements in the labour market have been sizeable and rapid. Both registered and surveyed unemployment are well below the OECD average of 7 percent and the EU average of 10 percent. The participation rate was 85.9 percent in August, which is close to its peak of 87.4 percent in July 2007.

Purchasing power has also grown steadily since 2010. Last year it grew by 5.5 percent over the previous year, and has increased in 2016. In August 2016, purchasing power had increased by 10.1 percent since the same month last year. 
The recent tourism boom has resulted in a substantial surplus in the balance of trade. The number of tourists visiting Iceland increased by roughly 30 percent in 2015 . The number of tourists departing from Keflavik Airport has increased by 34 percent in the first seven months of 2016, compared to the same period last year. Even though the tourism industry is expected to stay strong in the coming years, further appreciation of the krona is a risk factor for the industry. Another risk factor is the devaluation of the GBP following the Brexit decision, as nearly 20 percent of tourists in Iceland come from the UK. Exports have been robust since 2008 and look as if they will be the main driver of GDP growth when import-intensive investment projects come to an end in 2017 and beyond.

Terms of trade have improved as oil prices have dropped. Statistics Iceland predicts further improvements in the coming years, mostly because of favourable developments in the prices of aluminium and seafood, but terms of trade remain poor compared to the pre-crisis years.

A surplus in the trade balance is expected throughout the forecast period, while a positive current account balance remains. The Central Bank of Iceland's interventions this year point to an underlying surplus in the balance of payments. The forecast considers the upcoming measures to remove capital controls, which could impact the balance of payment in the years ahead.

\subsection{Public finances}

The National Budget for 2016 provides for a surplus of ISK 15.3 billion, a balanced budget for the third consecutive year. The primary surplus continues to be significant, at 3.1 percent of GDP, which is larger than in most other countries at present.

Cancellation of import duties, reductions in individuals' income tax, and reduction of debt, plus a growing operating surplus, are the most salient features of the budget proposal. Also assumed is a new ISK 2.6 billion allocation to housing affairs and reduced taxation of rental income to encourage long-term renting. Budgetary allocations to healthcare, education, and social security will increase.

The ratio of general government debt to GDP has fallen rapidly in recent years. Gross debt is estimated to decline from 75 percent of GDP by the end of 2015 to approximately 38 percent by the end of 2021 . 
In accordance with recommendations from the IMF, the authorities have focused on simplifying the tax system and improving work incentives by lowering marginal tax rates. At the beginning of 2016, the first and second rates of the personal income tax were lowered, to 37.13 percent and 38.35 percent respectively, while the third rate was kept at 46.25 percent. A second phase of these reforms will take effect in 2017, lowering the bottom rate to 36.95 percent and abolishing the second rate.

In addition, reforms of value added tax (VAT) continue. In 2015, the gap between the standard rate and the reduced rate was narrowed by raising the reduced rate from 7 to 11 percent and lowering the standard rate from 25.5 to 24 percent. At the same time, commodity tax was abolished. In January 2016, the VAT tax base was broadened substantially as exemptions for passenger transport and tourism-related recreation were abolished. These activities are now subject to the reduced VAT rate. The VAT reform also extends to other areas, such as taxation of alcohol, cross-border trade in services and intangibles, in line with the OECD International VAT/GST Guidelines, and the construction sector. Another important reform in indirect taxation includes the two-phase repeal of many categories of custom duties in 2016-2017.

\subsubsection{Strategy for lifting capital controls}

In June 2015 , the Icelandic authorities introduced a comprehensive strategy to liberalise the capital account. The strategy involved a working plan in three steps:

- The first step was to solve the problem created by the failed financial institutions' estates.

- The second step involved solving the problem created by the amount of offshore króna, liquid ISK assets that are likely to seek exit from the domestic economy when capital controls are lifted, with negative impact on the exchange rate.

- The final step involved lifting capital controls on individuals and businesses.

\section{(a) First step: Financial institutions' estates}

The problem created by the financial institutions' estates has been completely solved. The winding-up of the failed banks has been completed, as all eight former commercial and savings banks have made composition agreements by meeting stability conditions. The retaliatory actions of the three large estates have been estimated at ISK 660 billion, 
of which ISK 384 billion are direct stability contributions. The revenues stemming from the stability contributions have been, and will continue to be, used to meet revenue losses from the special tax on financial undertakings and to reduce debt.

\section{(b) Second step: The offshore króna problem}

The remaining stock of offshore króna stands at about 9 percent of GDP, down from approximately one-third of GDP in 2009. The offshore króna assets are potentially more volatile than other króna denominated assets, and could have a significant impact on exchange rate stability and the foreign exchange reserves if restrictions on the transfer of off-shore króna were lifted entirely. The assets will continue to be subject to special restrictions intended to reduce the risk attached to achieving the objective of the strategy. By 1 September, the remaining stock of offshore króna had been placed in special blocked accounts, where it will remain while capital controls are being lifted on individuals and businesses.

\section{(c) Third step: Lifting capital controls on individuals and businesses}

In October, the Icelandic parliament Althingi passed amendments to the Act on Foreign Currency. Important steps are being taken to lift the capital controls in full. Through the

Act, consideration is given to easing controls on resident and non-resident individuals and legal entities in two steps; the first when the bill is passed and the second by the end of 2016 . With the measures provided for in the Act, the capital controls should not place substantial restrictions on most individuals, and in 2017, only a very few individuals should be affected. The Act does not stipulate the date for a full liberalisation of the controls, but the next steps in the capital account liberalisation process will presumably take place early in 2017.

The conditions for liberalisation of the controls are in many respects optimal, and there is no longer any threat from large individual risk factors such as the settlement of the failed banks' estates or the offshore króna problem. Despite favourable conditions, it is important that the capital controls be lifted in careful structured phases, particularly regarding strain on the liquidity position of the financial system and the balance of payments.

\section{(d) Capital flow management measures}

Under legislation passed in June, the Central Bank now has the authority to set rules on necessary capital flow management measures to temper inflows of foreign currency 
and influence the composition of such inflows. The measure is based on the application of special reserve requirements for new inflows of foreign currency, and is structured to reduce the risk potentially accompanying strong capital inflows by directly affecting the incentives for carry trade. The Foreign Exchange Act states that the holding period may be up to five years and that the special reserve ratio may be up to 75 percent. However, the Rules on Special Reserve Requirements for New Foreign Currency Inflows, which the Central Bank has published under the terms of the Foreign Exchange Act, set the holding period at one year and the special reserve ratio at 40 percent.

\subsubsection{Upgraded credit rating with stable outlook}

In September, Moody's upgraded Iceland's credit ratings to $A_{3}$ from Baa2. The rating outlook is stable. One reason for the upgrading is the progress of the plan for removal of capital controls. In a press release following the publication of the upgraded rating, Moody's notes that Iceland's rating trajectory had hampered the improvement of some of its core economic fundamentals since the financial crisis. This was because of the residual risks posed to economic and financial stability by the complex process of removing the capital controls. However, the upgrade now reflects Moody's expectations that the phasing out of capital controls will proceed smoothly to completion and not disrupt economic and financial stability.

Table 4: Key figures for the Icelandic economy

\begin{tabular}{lcccc} 
& 2015 & 2016 & 2018 \\
\hline Percentage change unless stated otherwise & & & & \\
& & & 5.7 & 3.7 \\
Private consumption & 4.3 & 7.1 & 0.9 & 1.5 \\
Public consumption & 1.0 & 1.8 & 7.4 & 1.4 \\
Gross fix capital formation & 18.3 & 21.7 & 4.9 & 3.6 \\
Exports of goods and services & 9.2 & 7.5 & 6.3 & 3.0 \\
Imports of goods and services & 13.5 & 15.4 & 4.4 & 3.0 \\
GDP - change from previous year & 4.2 & 4.8 & 2.4 & 3.4 \\
Consumer price inflation (annual rate) & 1.6 & 1.8 & 3.0 & 3.3 \\
Unemployment rate (annual average) & 4.0 & 3.1 & 3.1 & 3.3 \\
Current account balance (percent of GDP) & 5.1 & & & \\
\hline
\end{tabular}

Source: Statistics Iceland, May 2016, Ministry of Finance and Economic Affairs. 


\section{Norway}

\subsection{Economic outlook}

The fall in oil prices in 2014 marked the start of a powerful downturn in the Norwegian economy, involving lower income growth, higher unemployment and structural readjustment. Recently, growth in the mainland economy has increased, and the economy appears to have passed a turning point last winter. Should the present trend continue, with a registered unemployment rate well below the average over the past 25 years, the Norwegian economy will have come out of the slump in a better shape than was initially anticipated when the oil price started falling. However, economic growth is not strong. Unemployment figures based on Statistics Norway's Labour Force Survey are clearly higher than registered unemployment, and employment growth has been weak. Nonetheless, higher oil prices have helped reduce the risk of a sharp downturn in the Norwegian economy since last winter and spring.

Oil prices have risen since last winter, and forward prices indicate continued price growth. As a result, oil company revenues are improving, and the prospects for the supplier industry have improved somewhat. However, petroleum sector investments are expected to continue to fall next year, although at a slower rate than this year.

The economic improvement is supported by expansionary fiscal and monetary policies. Petroleum and fund revenue spending have been increased, and special measures to combat unemployment have been introduced. The key policy rate is at a record low, and the Norwegian krone has depreciated significantly. This is a clear benefit to exporters, suppliers to the petroleum industry and other businesses exposed to international competition in the Norwegian domestic market. While it may take some time for improved competitiveness to take effect, higher activity levels are already apparent in some industries, such as the tourism industry. Furthermore, Norwegian suppliers have won a greater share of assignments linked to the Johan Sverdrup field development, and fish export revenues have risen significantly. The depreciation of the krone is an important shock absorber in the Norwegian economy, and exports from the mainland economy are expected to rise in the future. 
Lower wage growth is also improving the competitiveness of Norwegian businesses. In line with the outcome of the wage settlement for sectors exposed to international competition, total annual wage growth is estimated at 2.4 percent for 2016, significantly lower than in preceding years. However, Norway's costs level remains substantially higher than the average for Norway's trading partners.

Consumers have become more optimistic in their assessment of the economic outlook. This is due not only to low interest rates and the fact that households are benefiting from tax reductions, but also to improved economic prospects. Strong growth in housing prices is a further indicator of greater optimism among households. However, weak real wage growth is expected to result in low growth in private consumption this year. The growth in total household demand for goods and services is expected to pick up in the years ahead. The increase in the number of start-up permits for new housing projects suggests strong housing investment growth in 2016 .

Businesses are also taking a brighter view of the future than before the summer, and anticipate rising production levels. Growth in public sector demand, improved competitiveness, and a slower decline in petroleum sector demand, have supported the positive trend.

While several confidence indicators suggest a positive trend, employment growth remains weak. Although the employment rate has been reduced by lay-offs in petroleum-related industries, the effect on unemployment has been mitigated by the transfer of young people into the educational sector and a drop in labour immigration. The unemployment trend has been clearly divided into two geographical areas since 2014. In southern and western Norway, and particularly Rogaland County, unemployment has risen sharply, but in most counties, registered unemployment has fallen over the past 12 months.

Overall, mainland Norway GDP is forecast to grow by 1.0 percent this year, about the same as last year. The growth estimate is 0.8 percentage points lower than forecast last autumn. Next year, growth is expected to increase to 1.7 percent before continuing to rise to a level slightly exceeding the trend for general growth in the economy.

All of these estimates are uncertain. Even though the household savings rate has fallen somewhat over the past year, most households are in a strong economic situation. Moreover, the level of corporate investment is relatively low. In isolation, both variables suggest that demand for goods and services may increase more sharply than currently anticipated but, if housing prices continue to grow strongly, the risk of a new downturn in the Norwegian economy will increase. 
Looking ahead, petroleum industry demand will decline as a proportion of the mainland economy, a development which has been accelerated by falling prices. Structural readjustments will be required, particularly in industries that supply goods and services to activities on the continental shelf.

Productivity growth fell in the middle of the previous decade, and the ageing population is likely to result in lower labour force expansion in the years ahead. Future growth is likely to be lower than in the 10 to 15 years preceding the summer of 2014, when oil prices began falling.

Norway's foremost current challenge is to bolster private businesses and facilitate growth and employment in sectors exposed to international competition. Low oil prices have brought about structural adjustments more rapidly than expected.

\subsection{Economic policy}

The Norwegian fiscal policy framework is designed to underpin stability and sustainability in an oil economy. By transferring all government petroleum income to the Government Pension Fund Global (GPFG) and, over time, aligning withdrawals with the expected real return on the Fund (estimated at 4 percent), the fiscal budget is better protected from fluctuations in petroleum revenues. It also ensures that current spending of petroleum income over the budget can be sustained.

The fiscal guidelines place much emphasis on stabilising economic fluctuations. Importantly, the automatic stabilisers do work, since petroleum revenue spending is measured using the structural, rather than actual, non-oil deficit. The guidelines also allow the fiscal budget to be actively used to stabilise the economy.

Monetary policy is the first line of defence against a cyclical downturn. Interest rates may be changed swiftly in response to economic prospects. The current low interest rate implies that the scope for additional or major interest rate reductions is limited. A very low interest rate will, over time, also entail a risk of mounting financial imbalances and more risk-taking in the financial sector.

Fiscal and monetary policies need to interact when the economy is exposed to a cyclical downturn. All in all, Norway's economic policy is now highly expansionary. In 2016, petroleum and fund revenue spending will increase by 1 percent of trend-GDP for mainland Norway, considerably above the average for the past 10 to 15 years. The Government will continue to pursue a fiscal policy aimed at counteracting the prospects 
of sub-trend growth next year, albeit on a smaller scale. Moreover, the Government is proposing about NOK 4 billion in special measures to promote employment, with an emphasis on areas and sectors hit hardest by the downturn in the petroleum industry. The Government's proposal will provide a fiscal budget stimulus equivalent to 0.4 percent of trend-GDP for mainland Norway next year.

Measured in NOK, the capital of the GFPG has grown very rapidly in recent years. However, almost half of the increase in the Fund's value over the three-year period 2013-2015 was due to the depreciation of the krone, and has not resulted in greater international purchasing power. In 2016, the krone exchange rate has appreciated somewhat, reducing the value of the Fund. Looking ahead, Norway must be prepared for substantial fluctuations in the value of the Fund.

Although the adopted framework helps to shield the Norwegian economy against short-term fluctuations in oil prices, lower oil prices mean that Norway has become less wealthy. Low international interest rates have weakened the Fund's real return prospects. It is likely that the real return will be below 4 percent for the next 10 to 15 years. This restricts the scope for further increases in petroleum and fund revenue spending. The next few years are likely to see the start of a downward trend in the fund return, measured as a proportion of mainland economic growth. 
Table 5: Key figures for the Norwegian economy

Percentage change unless stated otherwise

Private consumption

Public consumption

Gross fixed investment

- Public sector

- Petroleum extraction and pipeline transportation

Demand from Mainland Norway ${ }^{1}$

Exports

Of which: Traditional goods

Imports

Gross domestic product

Of which: Mainland Norway

$\begin{array}{rr}2.1 & 1 \\ 2.1 & 2.6 \\ -3,8 & 0 \\ 3.0 & 5 \\ -15.0 & -14 \\ 1.8 & 2.5 \\ 3.7 & -0.3 \\ 5.8 & -1.5 \\ 1.6 & -0.5 \\ 1.6 & 1 . \\ 1.1 & 1.0\end{array}$

1.4
2.6
0.0
5.3
-14.0
2.5
-0.3
-1.5
-0.5
1.2

2.3

2.6

\section{Labour market}

Employment, persons (percent change)

\section{Prices and wages}

Annual wage

Consumer price index (CPI)

Underlying inflation (CPI-ATE)

Oil price (NOK per barrel2)

$\begin{array}{rrrr}2.8 & 2.4 & 2.7 & 3.0 \\ 2.1 & 3.4 & 2.0 & 1.9 \\ 2.7 & 3.0 & 2.1 & 2.0 \\ 430 & 371 & 425 & 447\end{array}$

Interest rates and exchange rates

Three-month money market rates (percent) ${ }^{3}$

Import-weighted exchange rate (yearly change) ${ }^{4}$

$\begin{array}{llll}1.3 & 1.1 & 1.0 & 1.0 \\ 9.4 & 2.8 & 0.1 & 1.0\end{array}$

Main numbers, National budget 2016

Structural, non-oil budget deficit (NOK billion)

- Fiscal impulse 5

Deviation from 4 percent path, (expected real return, NOK billion)

$\begin{array}{rrr}169.8 & 205.6 & 225.6 \\ 0.6 & 1.0 & 0.4 \\ -87.4 & -92.8 & -71.2\end{array}$

Note: 1) Excluding inventory changes.

2) Current prices.

3) Calculated based on forward rates in September.

4) A positive number indicates a depreciation of the krone.

5) Measured by the change in the structural, non/oil deficit as a share of trend-GDP of Mainland Norway.

Source: Statistics Norway, the Norwegian Labour and Welfare Administration, and Ministry of Finance. 



\section{Sweden}

\subsection{Economic outlook}

The Swedish economy grew rapidly in 2015 and GDP growth will also be relatively high in 2016, mainly due to strong domestic demand. Resource utilisation is expected to be more or less balanced. After two years of high growth rates, GDP growth is expected be slightly lower in 2017 and in line with historical growth. A contributing factor to the slowdown is that investments are only increasing at a moderate pace.

With the slow growth rates of the global economy, the export sector is not expected to substantially contribute to Swedish GDP growth. Instead, a steady increase in household consumption has underpinned growth in recent years, and this is expected to continue. The low interest rates, employment growth and an increasing disposable income contribute to continued increases in consumption. However, the introduction of the amortisation requirement in June 2016 could dampen the increase. Growth in government consumption was 2.6 percent in 2015 , the highest rate since 1998 . Consumption in the state sector grew strongly, but the growth rate was even higher in the municipal sector. Public consumption is expected to grow strongly in the coming years, mainly in the municipal sector. This is due to demographic changes, with a larger share of elderly and children in the population and a steady population increase due to immigration.

Gross fixed capital formation continued to grow in early 2016. The main driver was growing service sector investment, where the share of housing investment has increased steadily since 2013. Investments in industry, however, were weaker. One explanation for this may be that industrial companies' investment needs were relatively small during the first half of 2016, after remaining at a very high level at the end of 2015. After two strong years, investment growth in the business sector is expected to gradually subside. Industry is expected to meet external demand without substantial increases in investment. 
Residential investment, which previously made major contributions to the strong investment growth, is expected to continue to increase, but at a lower rate as resource utilisation in the construction sector becomes more strained. Public investment is expected to grow at a high rate in 2016 and 2017, mainly in the municipal sector. Municipal and county council investment plans, and the strong increase in investments during the first half of 2016 , suggest continued strong growth. The development is driven by demographic trends and the fact that older infrastructure and buildings need to be replaced.

Exports were weak in the first half of 2016, following a very strong performance in 2015. However, exports of services increased sharply, mainly driven by the strong performance of research and development services. The strong performance was temporary. Because of the temporary effect in 2015 , services exports declined at the beginning of 2016, but have since recovered slightly. Goods exports also grew strongly in 2015, largely due to increased exports of motor vehicles. Exports of goods decreased in the first half in 2016 due to flat export market growth. International growth is expected to rise slightly in 2017 and result in higher demand for Swedish goods and services, and thereby an increase in export growth. Net exports are expected to turn negative in 2016, as export growth has been weak while imports have increased. Also, in 2017 the contribution of net exports to GDP is projected to be lower than the historical average, because of increased domestic demand leading to higher import growth.

The labour market grew strongly in 2015. Employment increased by 1.4 percent and unemployment decreased to 7.4 percent. For women, unemployment was 7.2 percent and for men 7.5 percent. Leading indicators show that employment will continue to increase. Unemployment has continued to fall during the first half of 2016, more for women than for men. For the full year 2016, unemployment is expected to be 6.8 percent, which is the lowest level since 2008. Unemployment is expected to fall further in 2017, to 6.3 percent. To reach its target of the lowest unemployment in EU by 2020, the government will continuously present reforms that reduce unemployment. Employment is expected to increase at high rates, which is partly related to high labour demand in municipalities. However, productivity growth in the economy is expected to be muted because of a large increase in hours worked in the public sector,

Monetary policy in Sweden is expansionary, with the repo rate at -0.5 percent since February 2016. The Riksbank is also implementing quantitative easing, as it purchases bonds. Despite the low interest rate, inflation is expected to be only 1 percent in 2016, and the repo rate is expected to remain very low in 2016 and 2017. 
As in many other advanced countries, wage rises have been low despite falling unemployment. Wages are expected to increase more in 2017, as resource utilisation in the labour market increases.

\subsection{Public finances}

The general government deficit was reduced by 1.5 percent of GDP between 2014 and 2015 , reaching a small surplus last year. A balanced budget is also expected in 2016 . The strong recovery of the Swedish economy and a prudent fiscal policy contributed to this considerable strengthening of the public finances.

An unprecedented increase in the number of refugees in 2015 will put pressure on expenditure in the short term. It is reasonable to allow exceptional and temporary events of this kind to be accommodated without requiring short-term contractionary budgetary measures. Public debt is low and estimated to be on a downward trend. This provides fiscal capacity to accommodate these expenditure increases in a socially and economically responsible way, without jeopardising the long-term sustainability of public finances.

The Government intends to pursue a prudent fiscal policy in the coming years. Refugee-related expenditure is expected to increase somewhat in 2016 and 2017, and then decline. General government net lending is estimated to increase in the following years - net lending will be in near balance in 2018 and reach a surplus of 1.5 percent of GDP in 2020.

When the current government came into power, it inherited a structural deficit of almost 1 percent. This was mostly due to permanent expansionary fiscal policy (essentially on the tax side) during the crisis. The government has pursued a tight fiscal policy that has gradually strengthened the structural position of the public finances. It is committed to restore the public finances to surplus, but at a pace that will not hinder the recovery in resource utilisation and long-term growth prospects. 
The fiscal stance (viewed as year-on-year change in the structural balance) has been tight in 2015 and 2016. For example, the increase in the number of refugees in 2015, combined with higher investments in the local government sector and weaker growth in the social security fund (pension system), has lowered the structural balance in 2016 and 2017. Therefore, the fiscal stance is somewhat expansionary in 2017 even though the output gap is more or less closed from 2016. While the fiscal stance is somewhat procyclical in 2017 , the unemployment rate is still relatively high and inflation is low.

Based on a no policy change projection, the central government budget balance will improve the structural saving ratio from 2018 and onwards. This will help the government keep its path towards putting the public finances back to a structural position in line with targets in the medium term.

\subsection{A new surplus target}

Today's fiscal framework emerged from the difficult fiscal situation in the early 1990 . The previous broad guidelines for economic policies were replaced with clear targets for budget policy. Initially, the aim was to stabilise debt, with annual savings targets. When this was achieved, a target was introduced for the public sector financial balance over the economic cycle. The fiscal policy framework, with its wide parliamentary support, is and has been of great benefit to Sweden and the Swedish economy. In late June 2016, an all-party parliamentary committee reached an agreement to recommend that the surplus target, currently at 1 percent of GDP over the cycle, should be reduced to one-third of a percent of GDP. The committee was of the view that this is consistent with a further reduction of gross debt to 35 percent of GDP, a debt to GDP level which, from 2019, should be used as a reference value for the subsequent ten years. 
Table 6: Key figures for the Swedish economy

\begin{tabular}{|c|c|c|c|c|c|}
\hline & 2013 & 2014 & 2015 & 2016 & 2017 \\
\hline \multicolumn{6}{|l|}{ Percentage change unless stated otherwise } \\
\hline GDP & 1.2 & 2.3 & 4.2 & 3.5 & 2.3 \\
\hline Private consumption & 1.9 & 2.2 & 2.7 & 3.1 & 2.7 \\
\hline Public consumption & 1.3 & 1.3 & 2.6 & 4.0 & 2.2 \\
\hline Fixed capital formation & 0.6 & 7.5 & 7.0 & 5.6 & 2.1 \\
\hline Stock building (contribution to growth) & 0.2 & 0.1 & 0.2 & 0.2 & -0.2 \\
\hline Exports & -0.8 & $3 \cdot 5$ & 5.9 & 4.2 & 3.9 \\
\hline Imports & -0.1 & 6.3 & $5 \cdot 5$ & 4.2 & 3.9 \\
\hline Net exports (contribution to growth) & -0.3 & -0.9 & 0.4 & -0.5 & 0.2 \\
\hline Productivity in private sector ${ }^{1,2}$ & 1.5 & 1.1 & $3 \cdot 3$ & 1.7 & 1.3 \\
\hline Hours worked $^{2}$ & 0.4 & 0.8 & 1.0 & 1.9 & 1.5 \\
\hline Employment 3 & 1.0 & 1.4 & 1.4 & 1.8 & 1.5 \\
\hline Unemployment 4 & 8.0 & 7.9 & 7.4 & 6.8 & 6.3 \\
\hline GDP gap 5 & -2.7 & -2.2 & -0.9 & 0.0 & 0.2 \\
\hline Wages $^{6}$ & 2.5 & 2.8 & 2.4 & 2.7 & 3.1 \\
\hline $\mathrm{CPI} 7$ & 0.0 & -0.2 & 0.0 & 1.0 & 1.5 \\
\hline Net lending ${ }^{8}$ & -1.4 & -1.6 & -0.1 & -0.2 & -0.3 \\
\hline
\end{tabular}

Note: 1) Value added at base prices per hour worked.

2) Calendar adjusted.

3) $15-74$ years.

4) Share of labour force $15-74$ years.

5) Difference between actual and potential GDP, as a percentage of potential GDP.

6) According to short-term wage statistics.

7) Annual average.

8) Consolidated general government. Percent of GDP. Outturn for net lending 2011-2014 has been revised after the publishing of the Budget Bill was published, net lending 2014 amounted to 67 SEK billion or 1.7 percent of GDP.

Source: Statistics Sweden and the Swedish Ministry of Finance. 



\section{Sammanfattning}

Denna rapport av den Nordiska konjunkturgruppen beskriver de ekonomiska utsikterna för de nordiska länderna. I Danmark väntas den måttliga ekonomiska återhämtningen fortsätta baserad på stärkt inhemsk efterfrågan. Den positiva utsikterna för privat konsumtion speglar den förbättrade situationen på arbetsmarknaden. Kapacitetsutnyttjandet stiger och investeringarna väntas gradvis öka. Finland är inne i en återhämtningsfas efter den tidigare ekonomiska recessionen. Inhemsk efterfrågan stiger men exporten utvecklas långsamt, delvis som en följd av fortsatt svag efterfrågan från Ryssland. Den norska ekonomin är på väg att förbättras sedan hösten 3015, då oljepriserna sjönk kraftigt. Samtidigt som konsumenter och företag har blivit mer optimistiska om de ekonomiska utsikterna fortsätter de låga oljepriserna att hämma tillväxten. I Sverige och Island har BNP utvecklats positivt som en följd av stark inhemsk efterfrågan. Framöver väntas dock tillväxten mattas av något. Tillväxten i Sverige har gynnats av såväl ökad konsumtion hos hushållen som stigande investeringar. 
Nordic Council of Ministers

Ved Stranden 18

DK-1061 Copenhagen K

www.norden.org

\section{Nordic Economic Outlook}

This report of economic developments in the Nordic countries has been prepared jointly by the Nordic Group of Macro-Analysts (Nordiska konjunkturgruppen) involving Experts from the Ministries of Finance.

TemaNord 2016:559

ISBN 978-92-893-4791-4 (PRINT)

ISBN 978-92-893-4792-1 (PDF)

ISBN 978-92-893-4793-8 (EPUB)

ISSN 0908-6692

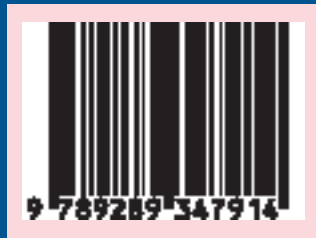

